and suggests that antenatal testing could prevent a significant proportion of vertical infection.

In a recent survey of all obstetric units in the British Isles, $51 \%$ were offering HIV tests only to women perceived as being at risk, $3 \%$ to all women, and the remainder had no formal policy. ${ }^{3}$ Our results show that in south east England, only $17 \%$ of live births to infected women are recognised before delivery. There is therefore considerable scope for improvement in antenatal HIV testing programmes.

We thank the obstetricians, midwives, paediatricians, and other physicians who have participated in the reporting schemes, microbiologists reporting HIV seropositive children to $C D S C$ and $C D(S)$, and T Berry for her clerical help. This study is supported by the AIDS Education and Research Trust (AVERT). The unlinked anonymous testing programme is supported by the Medical Research Council. The British Paediatric Surveillance Unit is supported by the Medical Research Fund of Children Nationwide.

1 Hall SM, Glickman M. Report from the British Paediatric Surveillance Unit. Arch Dis Child 1990;65:807-9.

2 Davison CF, Ades AE, Hudson CN, Peckham CS. Antenatal testing for human immunodeficiency virus. Lancet 1989;ii:1442-4.

3 Davison CF, Holland FJ, Newell ML, Hudson CN, Peckham CS. Screening for HIV infection in pregnancy. AIDS Care 1993;5:135-40.

4 Public Health Laboratory Service AIDS Centre. AIDS and HIV-1 infection: United Kingdom. Communicable Disease Report 1993;3:20.

5 Communicable Diseases (Scotland) Unit. Monitoring the spread and impact of HIV infection in Scotland, 1982-1991. AIDS Scotland 1992;7:1-11.

6 Communicable Diseases (Scotland) Unit. ANSWER, Communicable Disease Scotland Weekly Report 1993:93/05.

7 National Study of HIV in Pregnancy. Quarterly Newsletter. Horsham: AIDS Education and Research Trust (AVERT), 1992:Issue 13.

8 Lynn R, Hall SM. The British Paediatric Surveillance Unit: activities and developments in 1990 and 1991. Communicable Disease Repon 1992;2: R145-8

9 Centres for Disease Control. Classification system for human immunodeficiency virus (HIV) infection in children under 13 years of age. MMWR 1987;15:225-36.

10 Ades AE, Parker S, Berry T, Holland F, Davison C, Cubitt D, et al. Prevalence of maternal HIV-1 infection in Thames regions: results from anonymous unlinked neonatal testing. Lancet 1991;337:1562-65.

11 Sekar CC, Deming WE. On a method of estimating birth and death registration and the extent of registration. American Statistical Association fournal 1949;44:101-15.

12 Sato PA, Chin J, Mann JM. Review of AIDS and HIV infection: global epidemiology and statistics. AIDS 1989;3(suppl):S301-7.

13 Ades AE, Parter S, Cubitt D, Davison C, Holland F, Berry T, et al. Two methods for assessing the risk-factor composition of the HIV-1 epidemic in heterosexual woman: southeast England 1988-1991. AIDS 1992;6:1031-6.

14 Tappin DM, Girdwood RW, Follett EA, Kennedy R, Brown AJ, Cockburn F. Prevalence of maternal HIV infection in Scotland based on unlinked anonymous testing of newborn babies. Lancet 1991;337:1565-7.

5 Rouzioux C, Mayaux MJ, Blanche S, Burgard M, Griscelli C. The maternofetal transmission rates of HIV-1 and HIV-2 in France. VIII International Conference on AIDS, Amsterdam 1992: abstract WeC 1063.

16 European Collaborative Study. Children born to women with HIV-1 infection: natural history and risk of transmission. Lancet 1991;337:253-60.

17 Kind C, Brandle B, Wyler CA, Calame A, Rudin C, Schaad UB, et al. Epidemiology of vertically transmitted HIV-1 infection in Switzerland: results of a nationwide prospective study. Eur $\mathcal{Y}$ Pediatr 1992;151:442-8.

18 Auger I, Thomas P, De Gruttola V, Morse D, Moore D, Williams R, et al. Incubation periods for paediatric AIDS patients. Nature 1988;336:575-7.

19 Jones DS, Byers RH, Bush TJ, Oxtoby MJ, Rogers MF. Epidemiology of transfusion-associated acquired immunodeficiency syndrome in children in the United States, 1981 through 1989. Pediatrics 1992;89:123-7.

20 Tovo PA, Martino M, Gabiano C, Cappello N, D'Elia R, Loy A, et al. Prognostic factors and survival in children with perinatal HIV-1 infection. Lancet 1992;339:1249-53.

21 Blanche S, Tardieu M, Duliege AM, Rouzioux C, Le Deist F, Fukunaga K, et al. Longitudinal study of 94 symptomatic infants with perinatally acquired human immunodeficiency virus infection. Am f Dis Child 1990; 144:1210-5.

22 Thomas $P$, Singh $T$, Williams $R$, Blum $S$. Trends in survival for children reported with maternally transmitted acquired immunodeficiency syndrome in New York City, 1982 to 1989. Pediatr Infect Dis f 1992;11:34-9.

23 Scott GB, Hutto C, Makuch RW, Mastrucci MT, O'Connor T, Mitchell CD, et al. Survival in children with perinatally acquired human immunodeficiency virus type 1 infection. N Engl 3 Med 1989;321:1791-6.

24 Hsu HW, Moye J, Kunches L Ng P, Shea B, Caldwell B, et al. Perinatally acquired human immunodeficiency virus infection: extent of clinical population-based cohort. Pediatr Infect Dis f 1992;11:941-5.

25 Fischl MA, Dickinson GM, La Voie L. Safery and efficacy of sulfamethoxazole and trimethoprim chemoprophylaxis for Pneumocystis cariniipneumonia in AIDS. JAMA 1988;259:1185-9.

26 Dunn DT, Newell ML, Ades AE, Peckham CS. Risk of human immunodeficiency virus type 1 transmission through breast feeding. Lancet 1992; 340:585-8.

(Accepted 23 March 1993)

\title{
Assessing long term backache after childbirth
}

\author{
Robin Russell, Philippa Groves, Nicholas Taub, John O’Dowd, Felicity Reynolds
}

\section{Department of}

Anaesthetics, St Thomas's

Hospital, London SE1 7EH

Robin Russell, research

fellow

Philippa Groves, senior

registrar

Felicity Reynolds, professor

of obstetric anaesthesia

Department of Public

Health Medicine, United

Medical and Dental

Schools, St Thomas's

Hospital, London SE1 7EH

Nicholas Taub, lecturer

\section{Department of}

Orthopaedic Surgery,

St Thomas's Hospital,

London SE1 7EH

John O'Dowd, research

fellow

Correspondence to:

Dr Russell.

BMF 1993;306:1299-303

\section{Abstract}

Objectives-To investigate the factors associated with long term backache after childbirth, to assess all women reporting new onset long term backache, and to investigate any relation with pain relief in labour.

Design-Data collected from obstetric records and postal questionnaires or telephone interviews on morbidity after childbirth from all women delivering their first baby between March 1990 and February 1991, followed by analysis of data collected from outpatient consultations.

Setting-St Thomas's Hospital, London.

Subjects-Questionnaires were sent to 1615 women who had delivered their first baby in the defined period; 1015 either replied by post or were contacted by telephone.

Results-299 women (29.5\% of responders) reported backache lasting more than six months and of these $156(15 \cdot 4 \%)$ said they had had no back problems previously. Those women who had received epidural analgesia in labour were significantly more likely to report new onset backache $(17.8 \% ; 95 \%$ confidence interval $14.8 \%$ to $20.8 \%$ ) than those who did not $(11 \cdot 7 \% ; 8 \cdot 6 \%$ to $14 \cdot 8 \%)$. Younger women, unmarried women, and those reporting other antenatal symptoms were significantly more likely to report new long term backache. The 156 women reporting new backache were asked to attend an outpatient clinic and $36(23 \%)$ did so. The majority had a postural backache which was not severe. Psychological factors were present in 14 women.
Conclusions-Though new long term backache is reported more commonly after epidural analgesia in labour, it tends to be postural and not severe. There were no differences in the nature of the backache between those who had or had not received epidural analgesia in labour.

\section{Introduction}

The number of women choosing epidural analgesia in labour has steadily increased over the past 25 years. Until recently, relatively little research had been performed on the possible long term problems associated with epidural anaesthesia. MacArthur and her colleagues, in a survey of 11701 women, found an increased incidence of long term backache in those women who chose epidural analgesia in labour. ${ }^{1}$ It was postulated that the backache was postural, related to a combination of stressed positions in labour, muscular relaxation, effective analgesia and lack of mobility. However, no assessment of backache was made.

Backache is a problem that affects many people at some stage in life. Numerous disease processes cause backache, including inflammatory conditions, infections, developmental abnormalities, and mechanical and degenerative disorders. No study has investigated the nature of backache after childbirth. Our aim was to assess those women who had developed backache after childbirth and to look for any relation between backache and pain relief in labour or other factors. 


\section{Subjects and methods}

Nulliparous women who had delivered their first babies at St Thomas's Hospital between 1 March 1990 and 28 February 1991 were included in the study. Women who had had a stillbirth or neonatal death were excluded to avoid undue distress. We included only those women having their first baby as multiparous women may already be suffering with backache resulting from a previous delivery and thus could not develop new long term backache as a result of a more recent delivery.

Demographic and obstetric data were obtained from mothers' computerised hospital notes. Details of postnatal morbidity came from a postal questionnaire sent to each mother. These were sent in batches, 12-15 months after delivery. Mothers were asked about various symptoms including backache, headache, neck and shoulder pains, and urinary dysfunction; how long each had been present; and whether they had suffered from these problems before childbirth. If no reply had been received within six weeks, where possible the mothers were contacted by telephone and the questionnaire completed verbally.

Logistic regression ${ }^{2}$ was used to construct a model to show which mothers responded to the questionnaire, using the characteristics listed in table I. These variables together with data collected from the questionnaire were used to calculate a forwards stepwise logistic regression model for the development of long term backache; some variables were unconditionally included in the model because of their intrinsic relevance. Associations with individual binary characteristics were examined using the $\chi^{2}$ test.

The percentages of women reporting antenatal and postnatal symptoms were determined for the entire population, after which assessment was limited to the 753 women who had reported no backache before childbirth.

Women who had developed new long term backache were contacted and offered an appointment to assess their backache in more detail. In the clinic, each woman was seen by two anaesthetists and either an orthopaedic surgeon or a physiotherapist. Before consultation each woman completed a pain drawing ${ }^{3}$ and two psychological questionnaires, the modified somatic perception questionnaire ${ }^{4}$ and the modified Zung depression inventory, ${ }^{5}$ to assess any possible psychological component to the backache. The scores suggested as the upper "normal" limits in these

TABLE I-Logistic regression analysis of differences between responders and non-responders and factors involved in the development of backache after childbirth

\begin{tabular}{|c|c|c|}
\hline \multirow[b]{2}{*}{ Source of data } & \multicolumn{2}{|c|}{ Significance } \\
\hline & $\begin{array}{c}\text { Between } \\
\text { responders and } \\
\text { non-responders }\end{array}$ & $\begin{array}{l}\text { For development } \\
\text { of new long term } \\
\text { backache }\end{array}$ \\
\hline \multicolumn{3}{|l|}{ Data obtained from computer records: } \\
\hline Age & $\mathrm{p}<0.001$ & $\mathrm{p}<0.05$ \\
\hline Weight ${ }^{\star}$ & NS & NS \\
\hline Ethnic origin ${ }^{\star}$ & $\mathrm{p}<0.001$ & NS \\
\hline Marital status ${ }^{\star}$ & $\mathrm{p}<0.02$ & $\mathrm{p}<0.04$ \\
\hline Singleton or multiple pregnancy & NS & NS \\
\hline Onset of labour & NS & NS \\
\hline Total length of labour ${ }^{\star}$ & NS & NS \\
\hline Length of second stage of labour* & NS & NS \\
\hline Augmentation of labour ${ }^{\star}$ & NS & NS \\
\hline Epidural analgesia ${ }^{\star}$ & NS & $\mathrm{p}<0.01$ \\
\hline Mode of delivery ${ }^{\star}$ & NS & NS \\
\hline Birthweight ${ }^{\star}$ & NS & NS \\
\hline Perineal laceration or episiotomy & Not examined & NS \\
\hline \multicolumn{3}{|l|}{ Data obtained from questionnaire: } \\
\hline Contact by letter or telephone & & NS \\
\hline Other pain relief in labour ${ }^{\star}$ & & NS \\
\hline Antenatal neck and shoulder pain & & NS \\
\hline Antenatal headache & & $\mathrm{p}<0.005$ \\
\hline Antenatal abdominal pain & & $\mathrm{p}<0.02$ \\
\hline Other antenatal problems & & NS \\
\hline Breast feeding & & NS \\
\hline
\end{tabular}

model of factors involved in development of backache after childbirth
TABLE II-Association of variables with response to questionnaire using multiple logistic regression. (Odds ratios and $95 \%$ confidence intervals are relative to the first category and $p$ values for the overall significance of association with variables)

\begin{tabular}{lccc}
\hline $\begin{array}{c}\text { Number } \\
\text { of } \\
\text { women }\end{array}$ & $\begin{array}{c}\text { No }(\%) \\
\text { responding }\end{array}$ & $\begin{array}{c}\text { Odds ratio } \\
(95 \% \text { confidence } \\
\text { interval })\end{array}$ & p Value \\
\hline
\end{tabular}

\begin{tabular}{lllll}
\hline Age: & & & & \\
$<20$ & 180 & $85(47.2)$ & 1.00 & $<0.001$
\end{tabular}

$\begin{array}{rlll}\cdot 20-24 & 412 & 204(49.5) & 1.13(0.78 \text { to } 1.63)\end{array}$

$\begin{array}{llll}25-29 & 568 & 363(63.9) & 1.88(1.29 \text { to } 2.73)\end{array}$

$30-34 \quad 319 \quad 250(78 \cdot 4) \quad 3.38(2 \cdot 18$ to $5 \cdot 24)$

$>34 . \quad 136 \quad 113(83 \cdot 1) \quad 4 \cdot 75(2 \cdot 66$ to $8 \cdot 45)$

Race:

$\begin{array}{lllll}\text { European } & 957 & 672(70 \cdot 2) & 1.00 & <0.001\end{array}$

$\begin{array}{llll}\text { West Indian } & 263 & 144(54.7) & 0.82(0.60 \text { to } 1.13)\end{array}$

$\begin{array}{llll}\text { African } & 207 & 97(46.9) & 0.43(0.31 \text { to } 0.59)\end{array}$

$\begin{array}{llll}\text { Others } & 188 \quad 102(54.2) & 0.53(0.37 \text { to } 0.75)\end{array}$

Marital status:

$\begin{array}{lllll}\text { Unmarried } & 764 & 428(56.0) & 1.00 & <0.02\end{array}$

Married

Married

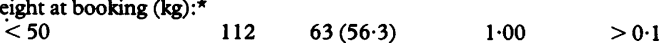

50-59

$60-6$

$>69$

Onset of labour:

$\begin{array}{lllll}\text { Spontaneous } & 1107 & 687(62 \cdot 1) & 1.00 & >0.1\end{array}$

Induced

Elective LSCS

Augmentation with Syntocin

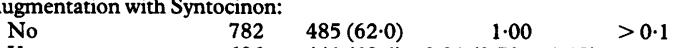

Yes

Epidural analgesia:

No

Yes 669

Length of labour (hours): $t$

$<4$

4-7

$8-11$
$>11$

$>1$
$<1$
Length
$1-2$

ength of 2nd stage of lab

$<1$

$1-2$
$2-3$

$>3$

Mode of delivery:

SVD

Forceps or ventouse

Rotation forceps

LSCS

Other

Birth weight (kg): $\int$

$<2 \cdot 5$
$2 \cdot 5-3 \cdot 5$

$>3 \cdot 5$

$441(63.4) \quad 0.91(0.70$ to 1.17$)$

$403(60.2) \quad 1.00>0.1$

$612(64.7) \quad 0.99(0.75$ to 1.30$)$

$97(60.6) \quad 1.00 \quad>0.1$

$326(60.3) \quad 1.02(0.68$ to 1.52$)$

$300(64.0) \quad 1.22(0.80$ to 1.86$)$

$\begin{array}{lll}308 \quad 203(65.9) & 1.24(0.78 \text { to } 1.97)\end{array}$

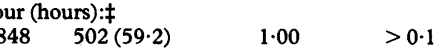

$384 \quad 244(63.5) \quad 0.96(0.72$ to 1.28$)$

$158 \quad 104(65.8) \quad 0.82(0.54$ to 1.24$)$

$45 \quad 34(75.6) \quad 1.26(0.58$ to 2.73$)$

$\begin{array}{llll}1002 & 599(59.8) & 1.00 & >0.1\end{array}$

$281 \quad 191(68.0) \quad 0.97(0.70$ to 1.35$)$

$\begin{array}{rrrr}39 & 31(79.5) & 1.39(0.59 \text { to } 3.28) \\ 282 & 187(66.3) & 0.69(0.43 \text { to } 1.10)\end{array}$

$282 \quad 187(66.3) \quad 0.69(0.43$ to 1.10$)$

$7(63.6) \quad 0.99(0.26$ to 3.71$)$

$\begin{array}{lll}551 \quad 370(67.3) & 1.16(0.73 \text { to } 1.84)\end{array}$

LSCS = lower segment caesarean section; SVD = spontaneous vaginal delivery.

*Data missing on 79 women.

$\dagger 137$ Elective caesarean sections not included.

$\$ 180$ Caesarean sections not included.

Data missing on 5 babies.

assessments are 2 for the pain drawing, 10 for the modified somatic perception questionnaire and 29 for the modified Zung. ${ }^{5}$ This assessment was followed by a thorough history and examination, during which evidence of illness behaviour was noted.5 After each consultation and diagnosis women were advised on further management of their backache and possible modes of treatment.

\section{Results}

A total of 1615 questionnaires were sent and 1015 replies were received. Of these, 895 were by post and 120 by telephone, an overall response rate of $62.9 \%$. There were no significant differences in postnatal morbidity between those who replied by post and those who completed the questionnaire by telephone.

Differences between those women who did and those who did not reply to the questionnaire were examined and, adjusting for other variables, three significant differences between the groups were found (table II). As maternal age increased so did the response rate $(p<0.001)$. Within each age group women of European or West Indian origin were more likely to reply than other women $(p<0.001)$. The response rate was also lower in unmarried women $(p<0.05)$. There was no significant difference between 
the epidural rates in the two groups (responders $60 \cdot 2 \%$, non-responders $55 \cdot 7 \%$ ).

Eighty nine of those women who responded had undergone an elective caesarean section without going into labour; 71 had been performed under epidural anaesthesia and 18 under general anaesthesia. Among the remaining 926 women, $541(58 \%)$ received epidural analgesia during labour. There was no significant difference between age bands in the use of epidural analgesia.

A total of 650 women $(64 \%)$ reported at least one postnatal symptom, of whom $477(46.9 \%)$ had problems lasting over six months. Many of the symptoms reported in the postnatal period had been present before delivery (table III). Low backache was the most commonly reported symptom.

In the population of 1015 women, 109 of the 612 who received epidural analgesia $(\mathbf{1 7} \cdot \mathbf{8 \%}$; confidence interval $14.8 \%$ to $20 \cdot 8 \%$ ) developed new onset backache compared to $47(11.7 \% ; 8.6 \%$ to $14.8 \%)$ of 403 of the women who did not receive epidural analgesia (table III). None of the other postnatal symptoms was significantly associated with epidural analgesia. Women reporting backache before labour were no less likely to have chosen epidural analgesia in labour. One hundred and fifty $(57 \%)$ of the 262 women who reported antenatal backache received epidural analgesia compared with $462(61 \%)$ who did not suffer with backache $(p>0 \cdot 1)$.

To examine the association of any possible factors related to the development of long term backache, a multivariable analysis was required to look at each factor independent of the others. A forwards stepwise logistic regression analysis was performed using the variables collected from questionnaires and data from the obstetric notes (table I). The 262 women who reported antenatal backache were excluded, as they could not have developed new backache. Table IV gives factors found to be significant from the analysis of the remaining 753 women. Women who were unmarried $(p<0.04)$ and those aged $20-24$ years $(p<0.05)$ were more likely than married women or those in other age groups to report new onset backache. As previously reported,' epidural analgesia during labour was a strongly predictive factor for the onset of long term backache $(p<0.01)$. Antenatal headache and abdominal pain were also associated with the development of long term backache.

Attempts were made to contact all 156 women who had developed backache since childbirth and invite them to attend an outpatient clinic. Seventy two women were contacted by telephone, from which 42 clinic appointments were made. Of the remaining 30 women, 24 said that they no longer suffered with backache and six refused to attend, giving no reason. A further four women had moved house, leaving no forwarding address. The other 80 women, who were not contactable by telephone, were sent a letter requesting that they contacted the investigators to
TABLE IV-Factors significantly associated with backache from forward stepwise logistical regression

\begin{tabular}{|c|c|c|c|}
\hline Factors & Total & $\begin{array}{l}\text { No }(\% ; 95 \% \text { confidence } \\
\text { interval) with backache }\end{array}$ & $\begin{array}{c}\text { p Value } \\
\text { (adjusting for } \\
\text { other variables) }\end{array}$ \\
\hline \multicolumn{4}{|c|}{ Antenatal headache: } \\
\hline $\begin{array}{l}\text { Yes } \\
\text { No }\end{array}$ & $\begin{array}{r}54 \\
699\end{array}$ & $\begin{array}{c}20(37 ; 24.0 \text { to } 50 \cdot 0) \\
136(19 \cdot 5 ; 16.5 \text { to } 22 \cdot 4)\end{array}$ & $<0.005$ \\
\hline \multicolumn{4}{|c|}{ Epidural analgesia: } \\
\hline $\begin{array}{l}\text { Yes } \\
\text { No }\end{array}$ & $\begin{array}{l}462 \\
291\end{array}$ & $\begin{array}{r}109(23.6 ; 19.7 \text { to } 27.5) \\
47(16.2 ; 11.9 \text { to } 20.4)\end{array}$ & $<0.01$ \\
\hline \multicolumn{4}{|c|}{ Antenatal abdominal pain: } \\
\hline $\begin{array}{l}\text { Yes } \\
\text { No }\end{array}$ & $\begin{array}{r}27 \\
726\end{array}$ & $\begin{array}{r}10(37.0 ; 19.0 \text { to } 55.0) \\
146(20 \cdot 1 ; 17.2 \text { to } 23.0)\end{array}$ & $<0.02$ \\
\hline \multicolumn{4}{|c|}{ 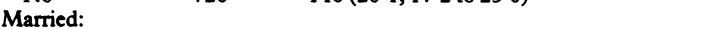 } \\
\hline $\begin{array}{l}\text { Yes } \\
\text { No }\end{array}$ & $\begin{array}{l}433 \\
320\end{array}$ & $\begin{array}{l}75(17 \cdot 3 ; 13 \cdot 8 \text { to } 23 \cdot 0) \\
81(25 \cdot 3 ; 20.5 \text { to } 30 \cdot 1)\end{array}$ & $<0.04$ \\
\hline \multicolumn{4}{|c|}{ Maternal age: } \\
\hline $\begin{array}{c}<20 \\
20-24 \\
25-29 \\
30-34 \\
>34\end{array}$ & $\begin{array}{r}61 \\
141 \\
281 \\
191 \\
79\end{array}$ & $\begin{array}{l}13(21 ; 11 \text { to } 32) \\
41(29 ; 22 \text { to } 37) \\
56(19 \cdot 9 ; 15 \cdot 3 \text { to } 24 \cdot 6) \\
33(17 \cdot 3 ; 11.9 \text { to } 22 \cdot 6) \\
13(16 ; 8 \text { to } 25)\end{array}$ & $<0.05$ \\
\hline
\end{tabular}

TABLE V-Assessment of backache and analgesia in labour in 36 women who kept appointment

\begin{tabular}{|c|c|c|}
\hline \multirow[b]{2}{*}{ Diagnosis } & \multicolumn{2}{|r|}{ Analgesia } \\
\hline & No & Type \\
\hline Postural backache $(n=29)$ & $\begin{array}{r}19 \\
8 \\
1 \\
1\end{array}$ & $\begin{array}{l}\text { Epidural } \\
\text { Pethidine } \\
\text { Nil } \\
\text { General anaesthesia }\end{array}$ \\
\hline $\begin{array}{l}\text { Postural backache plus sacroiliac pain } \\
\qquad(n=2)\end{array}$ & $\begin{array}{l}1 \\
1\end{array}$ & $\begin{array}{l}\text { Epidural } \\
\text { Entonox }\end{array}$ \\
\hline $\begin{array}{l}\text { Postural backache plus coccygeal pain } \\
(n=2)\end{array}$ & 2 & Epidural \\
\hline $\begin{array}{l}\text { Postural backache plus haematoma } \\
(\mathrm{n}=1)\end{array}$ & 1 & Epidural \\
\hline Spondylolisthesis $(n=1)$ & 1 & $\begin{array}{l}\text { Transcutaneous nerve } \\
\text { stimulation, } \\
\text { Entonox, } \\
\text { pethidine }\end{array}$ \\
\hline Intermittent disc pain $(n=1)$ & 1 & Epidural \\
\hline
\end{tabular}

discuss their backache with a view to arranging an outpatient appointment. Only 20 women replied, with 18 making an appointment and two reporting that they no longer suffered with backache.

Although 60 women made an appointment to be seen only 36 attended the clinic. Table $\mathrm{V}$ shows the analgesia these women received in labour. Twenty nine women had a purely postural backache. Typically, women described a dull ache across their lower back starting in the first few weeks after childbirth. The ache was usually exacerbated by lifting or bending and improved by resting. Usually the pain was not severe and did not affect daily life. Two of the women had consulted their general practitioners, one of whom had been referred to a physiotherapist; the other received simple oral analgesia. Examination showed only mild tenderness over the lumbar vertebrae. A further five women had postural backache combined with other problems. Two complained of pain over the sacroiliac

TABLE III-Incidence of antenatal and postnatal symptoms in responders ( $n=1015)$ with postnatal symptoms in women who had epidural analgesia $(n=612)$ and those who did not $(n=403)$. Values are numbers (percentage of responders)

\begin{tabular}{|c|c|c|c|c|c|c|}
\hline & \multirow{2}{*}{$\begin{array}{l}\text { Antenatal } \\
\text { symptoms } \\
\text { only }\end{array}$} & \multirow{2}{*}{$\begin{array}{c}\text { Antenatal and } \\
\text { postnatal } \\
\text { symptoms }\end{array}$} & \multirow{2}{*}{$\begin{array}{c}\text { Postnatal } \\
\text { symptoms } \\
\text { only }\end{array}$} & \multicolumn{2}{|c|}{$\begin{array}{l}\text { Postnatal symptoms } \\
\text { (95\% confidence intervals) }\end{array}$} & \multirow[b]{2}{*}{ p Value } \\
\hline & & & & Epidural & No epidural & \\
\hline Low backache & $119(11 \cdot 7)$ & $143(14 \cdot 1)$ & $156(15 \cdot 4)$ & $\begin{array}{c}109(17 \cdot 8) \\
(14 \cdot 8-20 \cdot 8)\end{array}$ & $\begin{array}{c}47(11 \cdot 7) \\
(8 \cdot 6-14 \cdot 8)\end{array}$ & $<0.05$ \\
\hline Neckache and shoulder pain & $32(3 \cdot 2)$ & $35(3 \cdot 4)$ & $58(5 \cdot 7)$ & $\begin{array}{l}35(5 \cdot 7) \\
(3 \cdot 9-7 \cdot 5)\end{array}$ & $\begin{array}{l}23(5 \cdot 7) \\
(3 \cdot 4-8 \cdot 0)\end{array}$ & $>0.1$ \\
\hline Headache & $47(4 \cdot 6)$ & $41(4 \cdot 0)$ & $38(3 \cdot 7)$ & $\begin{array}{l}20(3 \cdot 3) \\
(1 \cdot 9-4 \cdot 7)\end{array}$ & $\begin{array}{c}18(4 \cdot 5) \\
(2 \cdot 4-6.5)\end{array}$ & $>0.1$ \\
\hline Abdominal pain & $23(2 \cdot 3)$ & $17(1 \cdot 7)$ & $50(4 \cdot 9)$ & $\begin{array}{l}35(5 \cdot 7) \\
(3 \cdot 9-7 \cdot 5)\end{array}$ & $\begin{array}{l}15(3 \cdot 7) \\
(1 \cdot 9-5 \cdot 6)\end{array}$ & $>0.1$ \\
\hline Urinary dysfunction & 0 & $3(0 \cdot 3)$ & $37(3 \cdot 6)$ & $\begin{array}{l}18(2 \cdot 9) \\
(1 \cdot 6-4 \cdot 2)\end{array}$ & $\begin{array}{l}19(4 \cdot 7) \\
(2 \cdot 6-6 \cdot 8)\end{array}$ & $>0.1$ \\
\hline Other antenatal problems & $5(0.5)$ & $13(1 \cdot 3)$ & $35(3 \cdot 6)$ & $\begin{array}{l}22(3 \cdot 6) \\
(2 \cdot 1-5 \cdot 1)\end{array}$ & $\begin{array}{l}13(3 \cdot 2) \\
(1 \cdot 5-4 \cdot 9)\end{array}$ & $>0.1$ \\
\hline
\end{tabular}


joints. Again this was a dull ache starting soon after delivery and made worse by effort and relieved by rest. It was reproduced on examination by stressing the sacroiliac joints. Two other women with postural backache had also suffered with pain and tenderness over the coccyx starting immediately after delivery. This pain was worse after sitting for long periods but was steadily improving. One had delivered spontaneously, the other by outlet forceps. Another woman had tenderness over the site of epidural insertion in addition to postural backache. This was slowly improving but was still tender to palpation. There were no other physical signs. A resolving soft tissue haematoma was diagnosed. A woman who had been delivered by rotational forceps without epidural analgesia developed severe low backache the day after delivery. The pain radiated to both legs, was exacerbated by exercise, and had failed to resolve. A lumbar $x$ ray had revealed a spondylolisthesis of L5-S1 and she was awaiting an orthopaedic outpatient appointment. The remaining woman had had three episodes of severe backache since delivery, each lasting about a week. On each occasion the pain had been precipitated by lifting the baby. The pain, which radiated down both legs, was severe enough to force the woman to lie flat and rest. When she was seen in the clinic the pain had not been present for three months and examination revealed only tenderness over the L4-5 interspace with no neurological abnormality. A prolapsed intervertebral disc was diagnosed.

The women we were investigating had all reported no antenatal backache in the original questionnaire but, when asked directly, four women admitted to backache before childbirth. All were suffering from postural backache; two had received epidural analgesia during labour, one nitrous oxide and oxygen (Entonox) and pethidine, and one a general anaesthetic.

Of the 36 women seen, 14 had possible psychological factors related to backache, with nine scoring above the normal range in two or more of the assessments. Of the 14 women, 13 were diagnosed as having postural backache. Thirty three women completed the pain drawing, and of these, three scored more than two points. Thirty two women completed the modified somatic perception questionnaire, with nine women scoring 10 or more. Only 29 women completed the modified Zung questionnaire, with four scoring more than 29 points. Seven women had either symptoms or signs suggestive of illness behaviour. Two reported pain over most of their body combined with nonanatomical tenderness on examination. Three displayed non-anatomical tenderness, one combined with back pain on axial loading, and the remaining two overreaction on physical examination. Of the seven, three had scored above "normal" on the modified somatic perception questionnaire and modified Zung questionnaire and three had failed to complete them.

\section{Discussion}

It has been suggested that epidural analgesia in labour may cause long term backache.' The non-selective nerve block created by the epidural administration of local anaesthetics causes muscular relaxation in the lower back and legs, leading to poor posture and immobility. As a result, stressed positions in labour may damage the back and lead to long term backache. This theory has not, however, been proved in a prospective randomised study. Our results $(17 \cdot 8 \%$ new backache after epidural analgesia compared with $11.7 \%$ without epidurals) are similar to those reported by MacArthur et al $(18.9 \%$ with epidural, $10.5 \%$ without). The $6 \%$ increase in our study indicates a 1 in 17 chance that a woman will suffer backache as a result of epidural analgesia.
The response rate to our questionnaire was $63 \%$, with younger women, unmarried women, and women of African origin less likely to respond. Epidural analgesia was not a significant factor for response to the questionnaire. It may be that women who had developed postnatal symptoms would be more motivated to respond to the questionnaire, thus increasing the apparent incidence of symptoms. MacArthur $e t$ al, whose results were similar, also had a low response rate. ${ }^{\prime}$

Long term backache was also associated with antenatal headache and abdominal pain. Further analysis revealed that women reporting long term backache were more likely to report other symptoms than those who did not. Either these women were prone to tick boxes or their backache could be one facet of a multisymptom disorder. MacArthur et al found that various spinal axis symptoms were reported more commonly after epidural analgesia. ${ }^{6}$

Of the 156 women who had reported new long term backache most were reluctant to be seen in an outpatient clinic. Of those who were contacted by telephone and those who replied to the follow up letter nearly $30 \%$ said they no longer suffered with backache. Moreover, $40 \%$ of those women who agreed to attend the clinic did not keep their appointment despite both telephone and written confirmation. Also, of those sent letters inviting them to discuss their backache with a view to consultation, $75 \%$ failed to reply despite replying to the original questionnaire. Had the backache been serious, we would have expected more women to make an appointment to be seen in the clinic and fewer women fail to keep their appointments. Also, of those women contacted by telephone who failed to attend, none reported that they had been receiving any treatment for their backache. Further, our assessment of the 36 women who attended the outpatient clinic confirmed that most backache was postural and not severe. There were no differences in this respect between those women who had received epidural analgesia and those who had received other forms of pain relief.

We did, however, find other causes for backache. The aetiology of sacroiliac pain may be similar to that of low back pain, with ligamentous relaxation during pregnancy and stressed positions in labour being responsible. Dislocation and fractures of the coccyx are rare but recognised complications of childbirth, ${ }^{7}$ and haematoma formation at the site of epidural catheter insertion is uncommon but may cause prolonged local tenderness (unpublished observation).

Many women seemed unaware of the significance of poor posture during both labour and the postnatal period, choosing, where relevant, to attribute all their symptoms to the insertion of an epidural catheter. As posture would seem to be an important factor in the development of long term backache, there should be greater efforts to make mothers more aware of their posture. Women receiving epidural analgesia in labour must be carefully positioned to avoid stress on the lower back through labour and delivery. Advice must be given on how to lift, feed, and change the nappy of the new baby while putting minimal strain on the back. There is also a need for prospective studies to investigate if improving posture in labour and the postnatal period will result in less backache.

Indications that psychological factors may be contributing to the women's experience of back pain were found in 14 of the 36 women attending the clinic. In nine of these women characteristics outside the "normal" range were found in two or more different assessments. We are not suggesting that back problems are not present in these women, but they may coexist with emotional reactions to epidural analgesia in labour. In the United Kingdom there is a popular 
notion that epidurals cause long term backache ${ }^{8}$ If mothers who receive epidural analgesia expect to develop backache, back problems tend to become a focus of attention. A recent study in the United States, where women are not as conscious of any association, failed to show a correlation between epidural analgesia in labour and long term backache ( $T$ W Breen and N E Oriol, Society for Obstetric Anesthesia and Perinatology, Charleston, 1992). Many nulliparous women go into labour adamant that they will not have epidural analgesia, only to change their minds when the pain of labour becomes unbearable (W J K Rickford and F Reynolds, Society for Obstetric Anesthesia and Perinatology, Halifax, 1987). Such women may report backache more frequently, not only because of poor posture and muscular relaxation, but also because of their expectations of the possible long term effects of epidural analgesia.

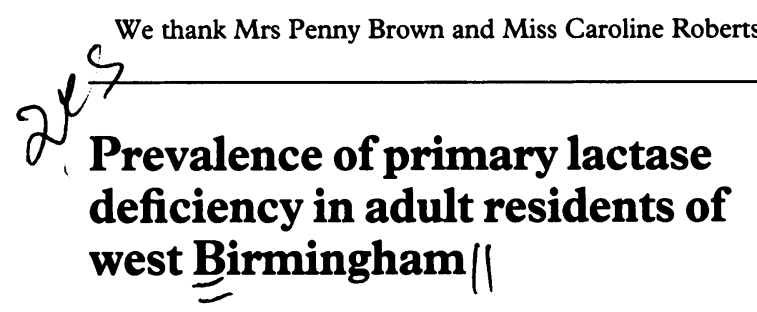

$$
\begin{aligned}
& \text { T H Iqbal, G M } \complement^{\text {Wood, } K} \text { OLLewis, J P Leek, } \\
& \text { B T Cooper }
\end{aligned}
$$

Gastroenterology Unit, Dudley Road Hospital, Birmingham) B17 7QH T H Iqbal, research fellow B T Cooper, consultant physician

Department of Clinical Chemistry, Dudley Road Hospital

KO Lewis, principal

biochemist

George Eliot Hospital, Nuneaton CV10 7BL

G M Wood, consultant physician

Department of Medicine, St James's University Hospital, Leeds LS9 7TF

J P Leek, chief technician

Correspondence to: Dr Cooper.

BMf 1993;306:1303 the physiotherapy department of St Thomas's Hospital for their help in the assessment of postnatal backache, and also Dr Phil Richardson for his assistance with the manuscript. Dr Russell was supported by a grant from the Sir Jules Thorn Charitable Trust.

1 MacArthur C, Lewis M, Knox EG, Crawford JS. Epidural anaesthesia and long term backache after childbirth. $B M$ I $^{1990 ; 301: 9-12}$

2 Dixon WJ. BMDP statistical software manual, volume 2. Berkeley: University of California Press, 1990:1013-46.

3 Ransford AO, Cairns D, Mooney V. The pain drawing as an aid to the psychologic evaluation of patients with low back pain. Spine 1976;1:127-34.

Main CJ. The modified somatic perception questionnaire (MSPQ). Journal of Psychomatic Research 1983;27: 503-14.

5 Waddell G. Understanding the patient with back pain. In: Jayson MIV, ed. The lumbar spine and back pain. 3rd ed. Edinburgh: Churchill Livingstone, lumbar spine
1987:419-34.

6 MacArthur C, Lewis M, Knox EG. Investigation of long term problems after obstetric epidural anaesthesia. BMY 1992;304:1279-82

7 Whitehead CR, ed. Dewhurst's textbook of obstetrics and gynaecology for postgraduates. 4th ed. Oxford: Blackwell, 1986.

8 Kitzinger S. Some women's experiences of epidurals: a descriptive study. London: National Childbirth Trust, 1987.

(Accepted 9 March 1993)
Lactose intolerance in late childhood and adult life is common in most of the world's populations, although northern Europeans are an exception. ${ }^{1}$ This intolerance is probably due to genetically determined primary lactase deficiency, but in developing countries it could result from lactase deficiency caused by damage to the small intestinal mucosa, especially that caused by enteric infections. There have been no studies of lactase activity in immigrants from developing countries resident in developed areas and only one on the prevalence of lactase deficiency in native white Britons. $^{2}$

The aim of the present study was to determine the prevalence of lactase deficiency in the two major immigrant groups resident in west Birmingham and to compare them with native white people.

\section{Patients, methods, and results}

We studied 67 white, 55 Indian, and 50 AfroCaribbean adult patients attending for routine upper gastrointestinal endoscopy for dyspepsia. Two biopsy specimens were taken from the junction of the second and third parts of the duodenum. One was processed for histological examination, and the other was frozen at $-20^{\circ} \mathrm{C}$ for later analysis for disaccharidase. Patients with intestinal disease were excluded. Lactase, sucrase, and maltase activities in the small intestinal brush border were measured by Dahlqvist's method $^{3}$ with a glucose oxidase colour reagent (Instrumental Laboratory IL test 181614-60). Ratios of sucrase to lactase activities were calculated, and a ratio of $>4$ signified primary lactase deficiency. ${ }^{4}$

To ensure that our patients were representative of the general population we performed a standard lactose hydrogen breath test on 20 healthy adult volunteers ( 10 Indian and 10 Afro-Caribbean) as an indirect assessment of small intestinal lactase activity. ${ }^{5}$ A rise in breath hydrogen of $20 \mathrm{ppm}$ over the baseline value at three hours after ingestion of $50 \mathrm{~g}$ lactose was considered positive.

No patient had partial or subtotal atrophy of the villi, and none had depressed sucrase or maltase activities in the brush border. Primary lactase deficiency was found in two (3\%) of the white patients, 28 $(55 \%)$ of the Indians, and $41(82 \%)$ of the AfroCaribbeans. According to the hydrogen breath test, six of the 10 Indians and seven of the 10 Afro-Caribbeans had lactase deficiency.

\section{Comment}

Our results show that lactase deficiency was commoner in the immigrant groups than in the white patients, in whom the prevalence was similar to that found in the previous study done in Britain (4.7\%). ${ }^{2}$ The similarity between the prevalence of lactase deficiency in patients and that shown by hydrogen breath testing in the volunteers suggests that the patients were probably representative of the general population.

Previous studies of residents of developing countries have often not been able to differentiate primary and secondary lactase deficiencies as causes of lactose intolerance. In our study the normal activities of maltase and sucrase enzymes in the brush borders of all patients with lactase deficiency have shown that the deficiency was primary and not secondary.

Although people with lactase deficiency vary considerably in the dose of lactose required to cause symptoms, ${ }^{4}$ the presence of the deficiency in such a high proportion of certain ethnic groups must be considered when abdominal symptoms in such people are assessed and when they are given any dietary treatment.

1 Flatz G. Genetics of lactose digestion in humans. In: Harris $\mathrm{H}$, Hirschhom $\mathrm{K}$ eds. Advances in human genetics. Vol 16. New York: Plenum, 1987:1-77.

Ferguson A, MacDonald DM, Brydon WG. Prevalence of lactase deficiency in British adults. Gut 1984;25:163-7.

Dahlqvist A. Method for assay of intestinal disaccharidases. Anal Biochem 1964;7:18-25.

4 Cooper BT. Lactase deficiency and lactose malabsorption. Dig Dis 1986;4: $72-82$.

5 Bond $\mathrm{JH}$, Levitt $\mathrm{MD}$. Use of pulmonary hydrogen $\left(\mathrm{H}_{2}\right)$ measurements to quantitate carbohydrate absorption-Study of partially gastrectomized patients. 9 Clin Invest 1972;51:1219-25.

(Accepted 23 March 1993)

\section{Correction}

Medical management of miscarriage: non-surgical uterine evacuation of incomplete and inevitable spontaneous abortion

This article by R C Henshaw et al (3 April, p 894-5) stated that sulprostone was voluntarily withdrawn by the manufacturer. It has not been withdrawn in countries where it has been licenced, but the usage has been restricted to intravenous use only. 